\title{
Pengaruh Media Sosial Terhadap Pendidikan Karakter Anak Di Masa Pandemi Coronavirus Disease 19
}

\author{
Madyan $^{1}$, Ahmad Baidawi ${ }^{2}$ \\ ${ }^{1}$ Universitas Islam Negeri Sulthan Thaha Saifuddin Jambi, Indonesia \\ ${ }^{2}$ Universitas Jambi, Indonesia \\ 2ahmadbaidawi84@gmail.com
}

\begin{abstract}
The influence of Social Media at this time is extraordinary. In addition to communication tools, social media can also act as an information center that allows users to find out all the information that is currently happening. On the other hand, social media can also be something that is very scary for us, especially for students. Some students misuse social media not for learning purposes but for unproductive things. During the current Covid-19 pandemic, the Indonesian government has adopted a policy of online learning or online learning. Online can also be interpreted as a situation where computers or laptops can exchange information, because they are connected to the internet network, this then makes all students must have a cellphone or laptop. When students use cellphones and computers, they also access social media. The role of social media for students in achieving success or supporting learning achievement is very large. The role of teachers and parents is expected to be able to help students in limiting themselves to excessive use of social media. The purpose of this article is to determine the extent of the influence of social media on children's character education, learning achievement, the negative and positive impacts of social media and the role of teachers in schools in limiting students' use of social media.
\end{abstract}

Keywords: Social Media; Education; School; Teacher; Covid 19

\begin{abstract}
Abstrak
Pengaruh Media Sosial pada saat ini sangat luar biasa. Selain alat komunikasi, media sosial juga bisa berperan sebagai pusat informasi yang memungkinkan penggunanya dapat mengetahui segala informasi yang terjadi saat ini. Pada sisi yang lain, media sosial juga dapat menjadi sesuatu yang sangat menakutkan bagi kita, khususnya bagi anak-anak peserta didik. Sebagian anak-anak peserta didik menyalahgunakan media sosial bukan untuk kepentingan belajar melainkan untuk hal-hal yang tidak produktif. Dimasa pandemi Covid 19 saat ini, pemerintah Indonesia mengambil kebijakan belajar secara daring atau belajar dalam jaringan. Daring juga bisa diartikan sebagai suatu keadaan di mana komputer atau laptop bisa saling bertukar informasi, karena telah terhubung dengan jaringan internet, hal ini lantas membuat semua peserta didik harus memiliki handphone atau laptop. Ketika peserta didik menggunakan handphone dan komputer maka ketika itu juga mereka mengakses media sosial. Peran media sosial bagi peserta didik dalam mencapai suatu kesuksesan atau menunjang prestasi belajar sangat besar. Peran Guru dan Orang tua sangat diharapkan untuk dapat membantu para anak didik dalam membatasi diri penggunaan media sosial yang berlebihan. Adapun tujuan dari artikel ini adalah untuk mengetahui sejauh mana pengaruh media sosial terhadap pendidikan karakter anak, prestasi belajar, dampak negatif dan dampak positif dari media sosial dan peran guru di sekolah dalam membatasi anak didik dalam penggunaan media sosial.
\end{abstract}

Kata Kunci: Media Sosial; Pendidikan; Sekolah; Guru; Covid 19 


\section{Pendahuluan}

Masa depan anak bangsa sangat tergantung pada mutu sumber daya manusia dan kemampuan para siswa atau peserta didiknya dalam penguasaan IPTEK illmu pengetahuan dan ilmu teknologi. Hal tersebut diwujudkan melalui pendidikan dalam keluarga, pendidikan masyarakat maupun pendidikan sekolah (Khanti: 2020). Pendidikan sekolah merupakan salah satu pendidikan formal yang dijalankan oleh anak didik. Namun dalam masa pandemi covid 19 ini pendidikan sekolah melakukan transformasi cara belajar dari tatap muka menjadi secara daring atau online.

Kebijakan terkait belajar secara daring pada masa covid 19 tercantum pada Surat Edaran Nomor 4 Tahun 2020 dari Menteri Pendidikan dan Kebudayaan (Mendikbud) Tentang Pelaksanaan Kebijakan Pendidikan di Masa Covid-19 yaitu secara Daring (Mendikbud: 2020). Pembelajaran secara daring yang kita fahami dan kenal saat ini adalah kegiatan aktivitas pembelajaran yang menggunakan atau memanfaatkan jaringan koneksi internet dengan fleksibilitas, aksesibilitas, konektivitas, dan kapabilitas untuk berbagai jenis interaksi pembelajaran (Sadikin: 2020). Pandemi Covid-19 memang membawa dampak yang cukup luas terutama dalam dunia pendidikan, pembelajaran yang biasa dilakukan secara tatap muka di sekolah berganti secara daring. Pendidik serta peserta didik dituntut untuk mampu menggunakan teknologi agar pembelajaran secara daring bisa berjalan secara baik. Berbagai sarana pembelajaran secara daring sudah dicoba, seperti melalui aplikasi zoom meeting, google Whatsapp Group, Youtube, e-learning dan beberapa media sosial. Hal ini mengharuskan para pendidik dan para siswa harus kreatif dan tetap aktif meskipun pembelajaran dilakukan secara daring. Ada banyak masalah yang dihadapi oleh para pendidik dan peserta didik dalam penggunaan teknologi online seperti masalah jaringan, perangkat pembelajaran yang kurang memadai, dan kurangnya pemahaman dalam menggunakan media sosial. Namun, pembelajaran secara daring ini tetaplah menjadi satu-satunya alternatif untuk menghindari kerumunan di sekolah-sekolah (Matdio: 2020). Pembelajaran (instruction) adalah usaha-usaha yang terencana dalam memanipulasi sumber-sumber belajar agar terjadi proses belajar dalam diri siswa. Secara konseptual, pembelajaran merupakan suatu sistem. Pembelajaran abad ke-21 merupakan pembelajaran yang harus mempersiapkan generasi abad ke-21 dengan kemajuan TIK (Teknologi Informasi dan Komunikasi) atau ICT yang berkembang begitu cepat. Perkembangan teknologi tersebut mempengaruhi berbagai aspek kehidupan termasuk pada proses pembelajaran ( Hayati: 2020).

Pembelajaran secara daring atau online tidak dapat dipungkiri akan membawa banyak kendala, baik yang dialami oleh guru, siswa, ataupun orang tua. Selain itu, pembelajaran secara online juga menuntut anak harus banyak stay di rumah. Sedangkan bagi orang tua siswa juga harus memaksimalkan tugasnya untuk mengontrol atau mengawasi dalam mendidik anak selama belajar di rumah. Tidak hanya itu saja, orang tua juga selain sebagai pendamping belajar dirumah mereka juga harus banyak belajar bagaimana membuat suasana pemebelajaran secara daring atau online ini menyenangkan dan tidak membosankan bagi anak. Kekuatan sinyal internet juga harus mendukung untuk pembalajaran online karena tanpa internet yang baik maka inti dari pembelajaran menjadi kurang maksimal.

Berbicara tentang media sosial atau media digital ada banyak para ahli yang mendefinisikan tentang media sosial dengan bahasa dan interpretasi yang berbeda-beda, namun makna dan nilainya tetap sama. Ada banyak mamfaat dari media social, dengannya pengguna bisa dengan mudah untuk berinteraksi, berpartisipasi, berbagi, dan menciptakan jejaring sosial. Akhirnya media sosial memungkinkan berbagai kegiatan kehidupan mudah terakses dengan informasi lebih cepat, tepat dan akurat, sehingga menjadi sarana 
komunikasi yang efektif. Perkembangan media sosial ini juga memunculkan kegiatan pembelajaran yang berbasis elektronik. Tidak terkecuali dalam menyajikan bahan pembelajaran melalui internet yang berisi konten informasi, data dan akses pembelajaran yang ditemukan dalam media sosial tersebut.

Perkembangan media social saat ini telah banyak membawa dampak, baik itu bersifat positif maupun negatif bagi dunia pendidikan anak khususnya dalam pendidikan karakter akhlak anak. Adapun dampak positif dari media sosial jika dikaitkan dengan nilai karakter anak maka ada banyak manfaat yang bisa kita ambil misalnya anak didik dapat belajar bagaimana cara beradaptasi, melakukan sosialisasi dengan publik dan mampu menjaga jaringan pertemanan, serta memudahkan anak dalam kegiatan proses belajar, karena dapat digunakan sebagai sarana untuk berdiskusi dengan teman mengenai tugas sekolah. Adapun dampak negatif penggunaan media sosial terhadap karakter anak juga sangat banyak diantaranya anak-anak lebih suka menggunakan handphone bukan untuk belajar tetapi untuk membuka media sosial misalnya; Facebook, WhatsApp, Instagram, TikTok dan bermain game online, hingga membuat anak lalai terhadap tugas-tugasnya serta menjadikan anak-anak malas untuk berpikir sehingga mengambil jalan untuk mencontek karya-karya orang lain, dan banyak dari anak didik sudah tidak lagi mementingkan mata pelajaran yang sudah diberikan oleh guru, mereka hanya fokus pada permainan sehingganya prestasi belajar mereka menurun.

Ada beberpa fungsi dari media sosial yang umum diketahui masyarakat diantaranya: Mencari berita, informasi, dan pengetahuan lebih cepat sebagaimana pengertian media sosial itu sendiri, Mendapatkan hiburan, Memungkinkan bagi pengguna media sosial melakukan sebuah komunikasi secara daring atau online, seperti membagikan status atau mengupdate status, memberitahukan kabar dan informasi, chattingan hingga menyebarkan sebuah undangan, sehingga komunikasi lebih mudah, dapat mengundang banyak tanggapan dari masyarakat umum, Sarana berbagi informasi hingga tingkat internasional, mempromosikan produk atau mengenalkan brand local pada dunia internasional, menghasilkan lapangan pekerjaan baru seperti membuka jasa sosial media marketing, admin media sosial, post to promote, dan tentunya dapat mengetahui sejauh mana kemampuan atau skill yang kita miliki secara pribadi. (Larasati: 2021).

Salah satu tempat pendidikan karakter adalah lingkungan sekolah, dimana lingkungan sekolah dapat membantu siswa dalam mengembangkan etika, karakter, nilai tanggung jawab melalui sebuah model pembelajaran, dan pengajaran sebuah karakter yang baik melalui nilai-nilai yang bersifat universal (Berkowitz \& Bier, 2005: 7). Pendidikan karakter adalah suatu hal yang positif, karena apa saja yang dilihat oleh anak didik terhadap perilaku guru sedikit atau banyak akan mempengaruhi karakter anak didik yang diajarnya. Pendidikan karakter juga merupakan suatu upaya yang dilakukan secara sadar dan sungguh-sungguh dari seorang guru kepada anak didik atau siswanya. Pendidikan karakter telah menjadi sebuah pergerakan pendidikan yang mendukung pengembangan sosial, emosional, karakter dan pengembangan etik para siswa. Pendidikan karakter juga dimaknai sebagai suatu pendidikan yang mampu mengembangkan karakter anak didik menjadi berkarekter yang mulia dengan cara mempraktikkan serta mengajarkan nilai-nilai moral yang baik dan mengajarkan bagaimana musyawarah dalam pengambilan suatu keputusan dengan cara yang beradab mengedepankan kepentingan orang banyak.

Berdasarkan permasalahan diatas yang sudah penulis paparkan, penulis berusaha untuk menjelaskan bagaimana pengaruh media sosial terhadap pendidikan karakter anak serta beberapa dampak yang di timbulkan dari media sosial baik dampak positif maupun dampak negatif serta bagaimana strategi yang bisa dilakukan oleh para guru serta para orangtua untuk menghindari dari dampak negatif media sosial bagi karakter anak. 


\section{Metode}

Jenis penelitian ini adalah Kualitatif yang merupakan pendekatan yang memberikan kesempatan kepada peneliti untuk dapat melakukan deskripsi dan interpretasi secara terperinci untuk mendapatkan holistik pemahaman (Sugiyono: 2014). Jenis penelitian ini dimaksudkan untuk memberikan gambaran mengenai masalah yang diteliti yaitu bagaimana pengaruh media sosial terhadap pendidikan karakter anak pada masa pandemi Covid 19. Metode pengumpulan data adalah penelitian kepustakaan yang didukung oleh media cetak seperti buku, majalah, koran, jurnal, dan juga media elektronik, terutama internet di mana data merupakan sumber sekunder. Data-data ini akan dianalisis dalam kerangka teori yang telah ditentukan untuk membuktikan bahwa hipotesis itu akurat dan akhirnya dapat menjawab pertanyaan penelitian. Analisis ini dilakukan melalui beberapa tahapan, yaitu: reduksi data, pemaparan data, deskripsi dan verifikasi serta menarik kesimpulan. Dalam penentuan informan penelitian ini menggunakan teknik purposive sampling. Yang mana dari beberapa jumlah informan yang ada akan ditentukan secara selektif untuk dipilih dan dianggap mampu menjadi informan atau memberi informasi yang diperlukan sesuai dengan tujuan penelitian. Adapaun metode pengumpulan data yang digunakan dalam penelitian ini adalah observasi, wawancara, dokumentasi, dan studi kepustakaan.

\section{Hasil dan Pembahasan}

\section{Media Sosial dan Pengaruhnya terhadap Pendidikan Karakter Anak}

Ada Banyak Pengaruh yang dimunculkan oleh media sosial terhadap pendidikan karakter anak dari mulai Aplikasi, Konten, dan Beberapa hal efek negatif yang muncul pada media sosial. Pertama, Aplikasi media sosial memiliki hubungan dalam pembentukan karakter anak. Aplikasi tersebut disesuaikan dengan kebutuhan anak seperti aplikasi yang bisa membantu proses belajar anak, meningkatkan pengetahuannya dan sosialisasinya. Semua tergantung dari aplikasi yang dipilih anak, jika anak memilih aplikasi yang mendukung aktivitas belajarnya, maka karakter anak akan terbentuk positif, sebaliknya jika anak memilih aplikasi yang membuatnya malas untuk belajar, maka karakter anak terbentuk negatif. Ini relevan dengan teori substansi yang sesuai dengan penggunaan media sosial dan pembentukan karakter. Inti dari penggunaan alat atau perangkat tergantung kepada substansi aplikasi, konten dan efek. Substansi yang berkaitan dengan media sosial yaitu seorang pengguna memanfaatkan sebuah aplikasi yang dapat digunakan untuk mencari informasi dan data yang berkaitan dengan tuntutan kebutuhan secara konten dan memberi efek positif maupun negatif. Berarti media sosial secara substansi ditentukan oleh penggunaan aplikasi, penjaringan konten dan menghasilkan efek yang mempunyai hubungan terhadap karakter seorang pengguna media sosial. Teori substansi ini relevan dengan konsep tindakan. Konsep ini dikemukakan Norman (2017) setiap orang bertindak sesuai dengan pertimbangan interpertatif atas situasi, interaksi, sosialisasi dengan berbagai referensi untuk bertindak secara rasional. Karena itu penggunaan media sosial mempunyai hubungan untuk menentukan karakter perilaku seseorang dalam bertindak. Intinya media sosial memiliki hubungan dengan pembentukan karakter anak tergantung dari aplikasi media sosial yang digunakan, apakah mempunyai hubungan membentuk karakter positif atau negatif kepada anak. Atas dasar itu perlu diperkenalkan, dibimbing, diawasi untuk memiliki aplikasi yang tepat dalam bermedia sosial.

Kedua, Konten media sosial memiliki hubungan dalam pembentukan karakter anak. Konten tersebut disesuaikan dengan kebutuhan anak yang harus menjadi perhatian orang tua untuk memberikan pengawasan apa saja yang anak lakukan dengan gadget 
mereka, agar jangan sampai anak membuka konten yang berbau negatif yang akan mempengaruhi karakternya menjadi negatif. Peran orang tua untuk bisa menjadi teman yang baik bagi anak, sehingga anak senantiasa terbuka dengan aktivitas yang dilakukan. Orang tua harus bisa memberikan informasi mengenai konten media sosial yang bisa memberikan manfaat bagi anak dalam pembentukan karakternya. Setiap orang membutuhkan informasi atau data untuk menambah referensi pengetahuan dan wawasan tentang banyak hal yang berkaitan dengan kehidupan. Itulah sebabnya banyak anak senantiasa mencari informasi tentang eksistensi dirinya termasuk melalui penggunaan media sosial. Informasi memuat pesan yang diperlukan sebagai referensi bagi anak yang mempunyai hubungan erat dengan pembentukan karakter seseorang. Dominasi pesan berperan penting membentuk karakter dominasi dalam diri seseorang. Apabila informasi berisi sumber-sumber pesan negatif. maka dengan mudah terbentuk karakter negatif, demikian pula sebaliknya.

Mengingat pentingnya informasi, maka konsep yang diperlukan untuk menangani pembentukan karakter adalah menggunakan konsep diri. Calhoun dan Acocella (2017) manusia mempunyai pandangan tentang dirinya yang mampu menggambarkan tentang diri dan kepribadian yang diinginkan sesuai pengalaman dan interaksi hidup yang dialami. Atas dasar itu, maka ada tiga dimensi yang menentukan konsep diri seseorang yaitu pengetahuan, pengharapan dan penilaian tentang dirinya sesuai kemampuan mengadopsi, menjaring dan mengaktualisasikan informasi yang didapatkannya. Intinya media sosial memiliki hubungan dengan pembentukan karakter anak tergantung dari konten media sosial yang dipilih. Biasanya konten menyajikan informasi pendidikan dan pengajaran akan memberikan efek positif dalam pembentukan karakter seorang anak. Namun konten yang berisi penyajian informasi yang bersifat negatif (gaya hidup, berita kriminal, serbaserbi yang tidak sesuai budaya dan nilai) biasanya menentukan karakter negatif dari seseorang.

Ketiga, Efek media sosial memiliki hubungan dalam pembentukan karakter anak. Ini menunjukkan media sosial secara keseluruhan memiliki efek yang negatif dan kurang baik dalam pembentukan karakter anak. Hal ini dikarenakan media sosial tidak hanya memiliki nilai positif, tetapi juga negatif tergantung pada aplikasi yang terdapat dalam handphone anak dan konten-konten negatif yang dapat didownload dengan mudah. Terlepas dari hal tersebut, orang tua harus terus mengawasi perilaku anak saat berada di rumah, apa saja yang dilakukan, menjadi teman bagi anak, sehingga anak bisa diajak untuk bertukar pikiran. Orang tua harus mampu memberikan penjelasan mana hal yang baik dan mana hal yang buruk. Ini memberikan pandangan bahwa anak dengan mudah terpengaruh dengan hal-hal yang dominan yang menjadi kesukaan atau favoritnya. Seperti halnya dalam penggunaan media sosial, secara bertahap dan berkesinambungan anak sekarang senang menggunakan media sosial dalam gadgetnya, yang secara sadar atau tidak sadar telah menentukan efek dominan dari media sosial yang diaplikasikan sesuai konten yang dibutuhkan.

\section{Pembalajaran Daring Pada Masa Pandemi Corona Virus Disease 19}

Corona Virus Disease 2019 (COVID-19) pertama kali didapatkan di kota Wuhan, China pada akhir bulan desember tahun 2019. Virus ini merupakan viru yang menular begitu cepat dan hampir ke semua negara di dunia, termasuk negara Indonesia, tidak perlu waktu yang lama hanya dalam hitungan beberapa bulan saja virus ini sudah masuk ke banyak Negara di dunia. Sehingga WHO dalam hal ini sebagai organisasi yang menangani masalah kesehatan masyarakat global langsung bertindak cepat dengan menetapkan sebahgai wabah yang mematikan dan sebagai pandemic global pada tanggal 11 Maret 
2020. Hal ini tentu membuat beberapa negara di dunia menetapkan kebijakan untuk memberlakukan lockdown dan work from home dalam rangka mencegah penyebaran virus corona di Negara masing-masing. Di Negara Indonesia sendiri, diberlakukan kebijakan Pembatasan Sosial Berskala Besar (PSBB) dengan tujuan untuk menekan angka penyebaran virus ini. Karena Indonesia sedang melakukan PSBB, maka semua kegiatan yang dilakukan di luar rumah harus dihentikan dan dialihkan kerumah masing-masing sampai pandemi ini mereda.

Beberapa pemerintah daerah juga telah memutuskan untuk menerapkan kebijakan yang telah diambil oleh pemerintah pusat terkait meliburkan peserta didik mulai dari jenjang paud sampai tingkat universitas dan mulai menerapkan metode pembelajaran secara daring atau online. Kebijakan pemerintah ini mulai berlaku di beberapa wilayah provinsi di Indonesia pada hari Senin, 16 Maret 2020. Tetapi hal tersebut tidak berlaku bagi beberapa sekolah di tiap-tiap daerah pada tingkat kabupaten, kecamatan dan desadesa dipelosok. Sekolah-sekolah tersebut tidak siap dengan sistem pembelajaran daring atau online, dimana pembelajran secara daring membutuhkan sebuah media pembelajaran seperti laptop, handphone dan komputer. Sistem pembelajaran daring atau online merupakan sistem pembelajaran yang dilakukan tanpa tatap muka secara langsung antara guru dan peserta didik tetapi dilakukan melalui daring atau online. Para guru harus memastikan kegiatan belajar dan mengajar tetap berjalan, meskipun peserta didik berada di rumah masing-masing. Implikasi dari pembelajaran secara daring atau online, para guru dituntut harus dapat mendesain media pembelajaran sebagai inovasi dengan memanfaatkan media sosial. Hal ini sesuai dengan Surat Ederan dari Menteri Pendidikan dan Kebudayaan Republik Indonesia Nomor 4 Tahun 2020 tentang Pelaksanaan Kebijakan Pendidikan dalam Masa Darurat Pandemi Corona Virus Disease (COVID-19).

Pembelajaran secara daring atau online sangat bergantung pada jaringan internet. Lemahnya koneksi jaringan internet menjadi salah satu kendala atau permasalahan yang sering dihadapi oleh para pendidik maupun peserta didik yang tempat tinggalnya sulit untuk mengakses internet, apalagi peserta didik yang rumahnya berada di daerah pedesaan, terpencil dan tertinggal. Kalaupun ada yang menggunakan jaringan seluler handphone terkadang jaringannya tidak stabil, karena letak geografis yang sangat jauh dari jangkauan sinyal jaringan seluler. Karena hal diatas, maka proses belajar mengjar kurang optimal pelaksanaannya. Bergantinya model sistem pembelajaran dari yang konvensional ke sistem daring atau online sangat membuat masyarakat khususnya para pendidik dan peserta didik merasa kaget Schock dan secara tiba-tiba tanpa melalui sebuah persiapan yang matang. Tetapi semua ini harus tetap terlaksana agar proses pembelajaran dapat berjalan lancar dan siswa dapat aktif mengikuti pembelajaran meskipun secara daring dan dalam kondisi pandemi Covid-19. Dalam sebuah proses pembelajaran secara daring atau online, para pendidik harus menyampaikan banyak pesan-pesan edukatif, berisi nilai-nilai dan moral serta etika yang baik kepada orangtua dan peserta didik, tentang wabah pandemi Covid-19 ini. Maka dengan itu, kita dapat mengambil hikmah atau sebuah pelajaran atas kejadian ini.

\section{Pendidikan Karakter}

Masalah moral dalam kehidupan bermasyarakat sampai saat ini masih saja terjadi, oleh karena itulah pendidikan karakter menjadi begitu esensial untuk dilakukan sebagai bentuk antisipasi problem sosial tersebut. Pendidikan karakter dapat dilakukan sebagai upaya yang sistematis untuk menjadikan perilaku yang negatif menjadi positif dan mengembangkan perilaku yang positif (Eka Setiawati: 2020). Sebelum memahami lebih jauh terkait pendidikan karakter, maka perlu dipahami makna dasar keduanya, yakni 
pendidikan dan karakter. Pendidikan merupakan upaya sadar untuk mengembangkan potensi anak didik kearah yang lebih baik, sementara karakter merupakan sifat dasar yang tumbuh dalam batin individu sehingga mempengaruhi sikap, perilaku, tindakan, atau memberikan warna tertentu pada aspek emosional, intelektual maupun relligiusitasnya. Dengan demikian pendidikan karakter dapat dipahami sebagai upaya mengembangkan potensi anak didik dengan menumbuh kembangkan sifat dasar batiniah agar menjadi pribadi yang baik dan luhur.

Pendidikan karakter adalah modal membangun dan membentuk watak sekaligus peradaban yang bermartabat sebagaimana fungsi pendidikan yang tercantum dalam perudang-undangan, yakni sebagai upaya mencerdaskan kehidupan bangsa. Pendidikan karakter juga adalah suatu hal yang mutlak harus dilaksanakan karena pada dasarnya semua guru sebagai pendidik memiliki tujuan yang sama dalam membentuk karakter anak bangsa. Dengan ini tidak lantas membuat pendidikan karakter hanya menjadi tanggungjawab dari seorang pendidik, tetapi menjadi tanggung jawab kita semua dalam memberi nilai-nilai seta norma yang baik (Santika, 2019: 79). Implementasinya adalah ketika pelaksanaan kurikulum 2013, dimana keseimbangan ranah pembelajaran antara kognitif, afektif dan psikomotor menjadi sebuah ouput atau tujuan yang mutlak dan harus sebagai bagian dari pendidikan karakter anak bangsa.

Karakter atau perilaku adalah sebuah watak pada diri seseorang atau sebuah ahlak yang diperoleh dari proses internalisasi seseoarang dengan lingkungan tempat tinggalnya. Karakter seseorang akan menjadi baik apabila dilandaskan pada nilai-nilai, moral dan etika kesponan yang berlaku dan disepakati di tengah masyarakat. Lickona (1992) menekankan tentang pentingnya tiga komponen dalam pembentukan karakter yang baik (components of good character), yaitu moral knowing atau pengetahuan tentang moral, moral feeling atau perasaan tentang moral, dan moral action atau perbuatan moral. Ketiga komponen karakter diatas akan muncul setelah ketiga kompenen karakter tersebut bisa terinternalisasi dalam kepribadian peserta didik. Ditambahkan oleh Nopan Omeri (2015) yang mengatakan karakter merupakan suatu perpaduan antara moral, etika, dan akhlak. Moral lebih menitikberatkan pada sebuah kualitas tindakan atau perbuatan. Sebaliknya, etika memberikan sebuah penilaian tentang sesuatu baik dan buruk, boleh, tidak boleh, indah atau tidak indah berdasarkan norma-norma yang berlaku pada suatu masyarakat tertentu. Sedangkan akhlak lebih menekankan pada hakikatnya dalam diri manusia itu telah tertanam sejak mereka dilahirkan. Faktor-faktor ini saling mendukung satu sama lainnya dalam membentuk kepribadian seorang anak (Santika dkk, 2019: 58).

Pendidikan karakter memiliki tiga fungsi utama. Pertama, Sebagai Pembentukan dan pengembangan potensi. Dalam fungsi pemebentukan dan pengembangan potensi ini seorang pendidik dituntut dapat membentuk serta mengembangkan potensi diri peserta didik atau siswa agar memiliki pikiran yang selalu optimis, positif dan pikiran yang baik, memiliki hati baik, dan dapat berperilaku sesuai dengan nilai-nilai serta falsafah Pancasila. Kedua, Sebagai Perbaikan dan penguatan. Dalam fungsi ini pendidikan karakter memiliki tanggung jawab dalam memperbaiki dan memperkuat peranan sebuah keluarga, satuan dalam pendidikan, masyarakat, dan pemerintah untuk ikut aktif berpartisipasi dan turut bertanggung jawab dalam mengembangkan potensi yang dimiliki warga negara dan ikut dalam proses pembangunan bangsa menuju cita-cita dari bangsa kita yaitu Negara yang maju, mandiri, dan sejahtera (welfare state). Ketiga, Sebagai Penyaring. Dalam fungsi yang ketiga ini pendidikan karakter dituntut dapat memperkuat budaya bangsa sendiri dan menyaring masuknya budaya asing atau budaya bangsa lain yang tidak cocok dengan nilainilai kearifan budaya bangsa dan karakter bangsa kita (Zubaidi, 2011:18). Dengan demikian dapat kita simpulkan bahwa dalam proses pembentukan karakter bangsa kita 
harus melibatkan semua elemen bangsa atau adanya suatu sinergitas (keterkaitan) dari ketiga komponen pendidikan yang ada diantaranya pendidikan informal, formal dan non formal.

Dijelaskan lebih lanjut ada empat alasan mendasar mengapa sistem pendidikan di Indonesia perlu menekankan pada pendidikan karakter, alasan tersebut yaitu: 1. Karena masih banyak dari keluarga baik yang bersifat tradisional maupun non tradisional yang masih belum melaksanakan dan mengamalkan nilai-nilai dalam pendidikan karakter; 2. Karena peran sekolah bukan hanya memiliki tujuan sebagai pembentuk anak menjadi cerdas, akan tetapi juga menjadi anak yang berprilaku yang baik; 3. Kecerdasan dari peserta didik atau anak hanya bermakna ketika anak itu dilandasi dengan perilaku yang penuh dengan kebaikan; 4. Membentuk peserta didik menjadi berkarakter tangguh dan mempunyai prinsip yang kuat bukan hanya sekadar tugas tambahan dari seorang guru, melainkan tanggung jawab yang utama yang sudah melekat pada peran seorang guru (Akin,1995:1). Dengan pendidikan karakter yang teritegarasi dalam proses pembelajaran ini menandakan pembelajaran yang bermakna yaitu kapabilitas yang berguna bagi kehidupan peserta baik untuk kepentingan belajar lebih lanjut maupun disumbangkan dalam pemecahan masalah di lingkungan masyarakat.

\section{Kesimpulan}

Berdasarkan hasil penelitian dapat disimpulkan beberapa hal. Pertama, Media sosial telah banyak memberikan efek baik itu efek positif ataupun negatif. Selain itu, media sosial juga menjadi penting saat ini. Penggunaan media sosial ditentukan oleh aplikasi, konten dan efek yang ditimbulkan dalam membentuk pendidikan karakter seorang anak didik. Dampak positif penggunaan sosial media, anak bisa ikut berpartisipasi dalam mencari materi pembelajaran serta membuat anak dengan mudah menyelesaikan tugastugasnya dengan menggunakan jaringan internet, media sosial juga dapat digunakan sebagai sarana pembelajaran, selain itu media sosial juga memberi manfaat terhadap pendidikan karakter sebuah akhlak anak didik misalnya anak didik dapat beradaptasi, melakukan sosialisasi diruang publik dan dapat mengelola jaringan sebuah pertemanan yang bak tentunya. Sebaliknya, media sosial juga dapat memberikan dampakyang tidak baik dan berdampak pada hal yang negatif, seperti membuat anak-anak tidak disiplin dan bermalas-malas, lupa waktu, sehingga tugasnya menjadi terbengkalai, membuat anak-anak memiliki karakter menyontek karya orang lain, Pendidikan karakter memiliki tiga Fungsi utama. Pertama, Fungsi Pembentukan dan Pengembangan Potensi Diri, Kedua, Fungsi Perbaikan dan Penguatan, dan Ketiga, Fungsi Penyaring.

\section{Daftar Pustaka}

Acocella, J. R., \& Calhoun, J. F. (1990). Psychology of adjustment human relationship (3th ed). New York: McGraw-Hill.

Berkowitz, M.W. \& Bier, M.C. (2005). What Works in CharacterEducation: A ResearchDriven Guide for Educators, Washington DC: Univesity of Missouri-St Louis.

Kementrian pendidikan dan kebudayaan. Surat Edaran No 4. Tahun 2020. Tentang pelaksanaan kebijakan pendidikan dalam masa darurat penyebaran corona virus disease (covid- 19 ).

Lickona, T. (1992). Educating for Character, How Our School Can TeachRespect and Responsibility. New York: Bantam Books.

Larasati Adira Dwicahyo. (2021). Pengaruh media sosial terhadap pendidikan karakter pelajar. diakses pada 23 Oktober 2021 dari Kabar Pendidikan, website: https://www.kabarpendidikan.id/2021/02/pengaruh-media-sosial-terhadap.html 
Noor Hayati, (2020). Pembelajaran di Era Pandemi. Yogyakarta: Deepublish.

Sadikin, A., \& Hamidah, A. (2020). Pembelajaran Daring Di Tengah Wabah Covid-19

(Online Learning in the Middle of the Covid-19 Pandemic). Biodik, 6(2), 214-224.

Sugiyono. (2014). Metode Penelitian Pendidikan Pendekatan Kuantitatif, Kualitatif Dan $R \& D$. Bandung: Alfabeta

Siahaan, M. (2020). Dampak Pandemi Covid-19 Terhadap Dunia Pendidikan. JKI: Jurnal Kajian Ilmiah Edisi Khusus No. 1.

Santika, I. G. N., Kartika, I. M., \& Wahyuni, N. W. R. (2019). Pendidikan Karakter: Studi Kasus Peranan Keluarga Terhadap Pembentukan Karakter Anak Ibu Sunah Di Tanjung Benoa. Widya Accarya. 10 (1), 54-66.

Sri Harnani. 2020. EFEKTIVITAS PEMBELAJARAN DARING DI MASA PANDEMI COVID-19. diakses pada 23 Oktober 2021 dari Website: https://bdkjakarta.kemenag.go.id/berita/efektivitas-pembelajaran-daring-di-masapandemi-covid-19.

Yo Ceng Giap \& Khanti Kusuma. (2020). Pembelajaran E-Learning di Masa Pandemi Covid-19. Yogyakarta: Deepublish.

Zubaedi. (2013). Desain Pendidikan Karakter. Jakarta: Kencana Prenada Media Group. 